\title{
Ranging characteristics of the domestic cat (Felis catus) in an urban environment
}

\author{
Rebecca L. Thomas • Philip J. Baker • \\ Mark D. E. Fellowes
}

Published online: 30 April 2014

C) The Author(s) 2014. This article is published with open access at Springerlink.com

\begin{abstract}
In many countries, high densities of domestic cats (Felis catus) are found in urban habitats where they have the potential to exert considerable predation pressure on their prey. However, little is known of the ranging behaviour of cats in the UK. Twenty cats in suburban Reading, UK, were fitted with GPS trackers to quantify movement patterns. Cats were monitored during the summer and winter for an average of $6.824 \mathrm{~h}$ periods per season. Mean daily area ranged (95\% MCP) was 1.94 ha. Including all fixes, mean maximum area ranged was 6.88 ha. These are broadly comparable to those observed in urban areas in other countries. Daily area ranged was not affected by the cat's sex or the season, but was significantly larger at night than during the day. There was no relationship between area ranged and habitat availability. Taking available habitat into account, cat ranging area contained significantly more garden and other green space than urban habitats. If cats were shown to be negatively affecting prey populations, one mitigation option for consideration in housing developments proposed near important wildlife sites would be to incorporate a 'buffer zone' in which cat ownership was not permitted. Absolute maximum daily area ranged by a cat in this study was $33.78 \mathrm{ha}$. This would correspond to an exclusory limit of approximately $300-400 \mathrm{~m}$ to minimise the negative effects of cat predation, but this may need to be larger if cat ranging behaviour is negatively affected by population density.
\end{abstract}

Keywords Domestic cat $\cdot$ Felis catus $\cdot$ Buffer zone $\cdot$ Ranging area $\cdot$ GPS

\section{Introduction}

The UK's pet cat (Felis catus) population is in excess of 10 million individuals (Murray et al. 2010) with an additional 800,000 feral cats (Harris et al. 1995), thereby far exceeding populations of any other mammalian carnivore (Harris et al. 1995). As pet cats receive supplemental food from their human owners, their densities do not reflect that of their prey, but are instead influenced by housing density (Sims et al. 2008; Thomas et al. 2012) and socioeconomic status (Murray et al. 2010). Therefore, cat populations may be exceptionally

R. L. Thomas $(\bowtie) \cdot$ P. J. Baker $\cdot$ M. D. E. Fellowes

School of Biological Sciences, Harborne Building, University of Reading, Whiteknights, Reading,

Berkshire RG6 6AS, UK

e-mail: rebecca.thomas@reading.ac.uk 
high in some urban areas (200-1,500 cats km ${ }^{-2}$ : Liberg et al. 2000; Baker et al. 2008; Sims et al. 2008; Thomas et al. 2012).

Domestic cats are opportunistic predators and will readily depredate what is available (Turner and Bateson 2000), responding to prey density and availability (Fitzgerald and Turner 2000). As a result of this behaviour and their artificially maintained high densities, domestic cats have the potential to exert considerable predation pressure on their prey (Loss et al. 2013). In one study of prey returned home by free-ranging urban domestic cats, 11 mammal, 21 bird and two reptile species were returned, with one species, the wood mouse (Apodemus sylvaticus) accounting for $40 \%$ of all prey (Thomas et al. 2012). Although the numbers and diversity of prey taken by pet cats have been widely investigated (Churcher and Lawton 1987; Barratt 1997b, 1998; Robertson 1998; Woods et al. 2003; Baker et al. 2005, 2008; van Heezik et al. 2010; Thomas et al. 2012; Loyd et al. 2013) the degree to which they may be negatively affecting wildlife populations in urban settings is still equivocal (Crooks and Soulé 1999; Lilith et al. 2010). Furthermore, while most studies have considered the direct effects of cat predation, other studies have emphasised the potential negative indirect consequences of domestic cats (Beckerman et al. 2007; Bonnington et al. 2013), further depressing prey numbers in areas with high cat densities.

Areas important for biodiversity conservation in many developed countries are increasingly being encroached upon by urban development (e.g. for the UK, Goddard et al. 2009) and the issue of cat predation has been raised as a potential problem in housing developments constructed near these areas. Some developers have discussed a ban on cat ownership on new developments built in close proximity to important conservation areas, but many believe that such bans would not be enforced (Leake and Cracknell 2006). Understanding the movement and behaviour of domestic cats is important in understanding their potential predatory effect (s) within an area, especially as a cat's range may encompass areas of high wildlife value. For example, Lilith et al. (2008) suggested a buffer zone of $360 \mathrm{~m}$ around any housing development in Australia to reduce the numbers of pet cats hunting in important wildlife areas. Such figures may, however, not be directly translated to other countries because of inter-national differences in urban landscape structure and, perhaps, differences in the abundance and types of prey species available. Additional data are, therefore, required on the range size of urban cats in different countries.

An animal's home range will usually contain areas in which it will be able to find food, rest and reproduce (Burt 1943). Free-ranging pet cats are, however, rather unusual in that they are fed and provided with shelter at the same point such that their owner's home is likely to be a strong focal element in their ranging behaviour. The cat may also be neutered, so they may not be driven by a strong desire to mate. Furthermore, range size may be negatively affected by cat density and the dispersion of natural food sources (Liberg et al. 2000).

Most research into home range and territory use of animals has been performed using radio tracking (Attuquayefio et al. 1986; Konecny 1987; Meek 2003; Harper 2007; Huck et al. 2008; Morgan et al. 2009). Although this technique has been widely used, there are well known issues with accuracy and the degree of resolution (Schmutz and White 1990), particularly in some habitats. Furthermore, tracking also frequently involves a human researcher directly following a focal individual such that it is possible that the act of tracking itself might affect the animal's behaviour (Maclean 2007). This may be particularly problematic with companion animals which might be expected to exhibit both attraction and avoidance responses to humans. One method for circumventing these problems, and gaining higher resolution spatial data, is through the use of global positioning systems (GPS).

Current estimates of home range sizes have focused mainly on feral or semi-feral cats (Liberg 1980; Apps 1986; Konecny 1987; Page et al. 1992; Mirmovitch 1995; Barratt 1997a; 
Edwards et al. 2001; Naidenko and Hupe 2002; Biro et al. 2004; Harper 2007; Schmidt et al. 2007; Recio et al. 2010) which are likely to have larger ranges than pet cats as they have to provision themselves (Barratt 1997a). Consequently, these will contain multiple food resources which may change in abundance throughout the year (Liberg et al. 2000; Harper 2007) possibly resulting in changes in range size, position or utilisation (Schmidt et al. 2007). In contrast, those of pet cats will be focused on their owner's home to which they return regularly to feed and rest throughout the day and night. As urban cats can attain higher densities than feral cats it is important to understand their movement behaviour and whether habitat complexity affects this trait (Horn et al. 2011).

Previous studies of the movements of urban domestic cats have been carried out in the USA, Australia and New Zealand, but with no previous studies in the UK (Table 1). Collectively, these have indicated no significant differences in range size between males and females (Barratt 1997a; Meek 2003; Morgan et al. 2009; Metsers et al. 2010; van Heezik et al. 2010) or between summer and winter seasons (Morgan et al. 2009), but an increase at night (Barratt 1997ba; Metsers et al. 2010: but see van Heezik et al. 2010). The complexity of habitat use by cats and the effect of habitat availability on ranging behaviour has not been investigated previously. Therefore in this study we used GPS tracking to obtain estimates of the area ranged by free-ranging pet cats in a large English town and how these varied in relation to (1) season, (2) sex, (3) day versus night and (4) habitat availability.

\section{Methods}

Study area and participants

The study was conducted in Reading, Berkshire, UK $\left(51^{\circ} 27^{\prime} \mathrm{N}, 0^{\circ} 58^{\prime} \mathrm{W}\right)$ during summer (6th July-6th August 2009) and winter (18th January-18th February 2010) seasons. Reading is a large town, $40 \mathrm{~km}$ west of London, which covers an area of $c .55 \mathrm{~km}^{2}$ and has a population of approximately 230,000 people. Twenty cats $(15 \hat{\jmath}, 5$ ㅇ) from 19 households were recruited by leaflet dropping and door-knocking (Thomas et al. 2012). All cats in the study were neutered and had unrestricted access to the outdoors through a cat flap.

\section{Data collection}

GPS receivers (CatTrack ${ }^{\mathrm{TM}}$, Perthold Engineering, USA) were used to record cat movement behaviour. Units were attached using a specially designed harness, so that the receiver was positioned on the back of each cat, behind the shoulder blades. Each harness was fitted with a safety break-away clip so that it would come off if the cat became entangled. GPS units weighed $22 \mathrm{~g}(4.4 \times 2.7 \times 1.3 \mathrm{~cm})$ and the harness approx. $40-45 \mathrm{~g},<5 \%$ of each cat's body mass, and were powered by a lithium battery.

GPS receivers were programmed to record a location every minute, although when unable to get a signal they would not record until a signal was re-established. All GPS systems will have some form of error when calculating location points. The error for this system was calculated in a number of different conditions (indoors, outside under cover, outside clear) along a predetermined $1 \mathrm{~km}$ route in June 2009. The deviation of each point from the route was measured in ArcGIS Version 9.3 (ESRI 2011) and on average recorded within an accuracy of $6 \mathrm{~m}$ (range $0-10 \mathrm{~m}$ ), although when indoors many fixes were missed.

Each cat was tracked for up to eight $24 \mathrm{~h}$ periods in each season, with a minimum of $24 \mathrm{~h}$ between tracking periods to minimise owners' concerns about the wearing of the harness for 


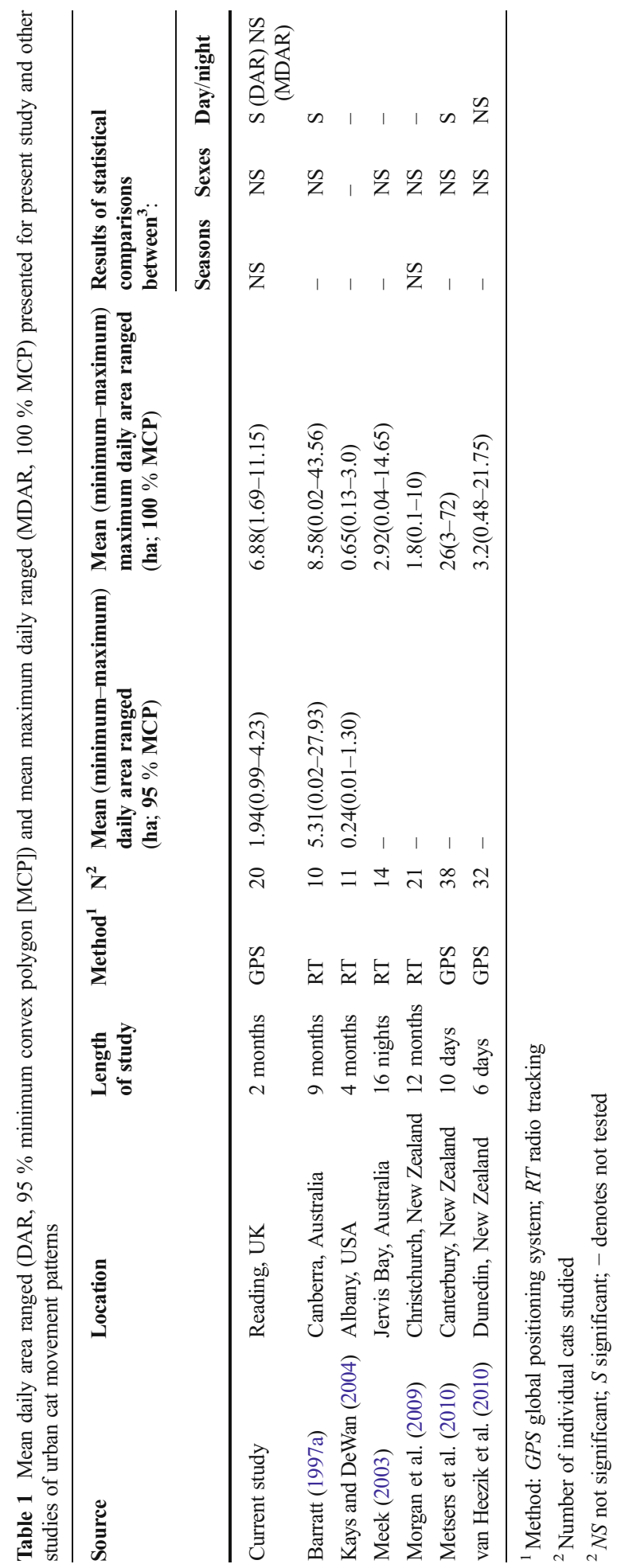


long periods of time. Cats were monitored by their owners during deployment and devices were removed immediately if any signs of distress were observed, although this did not happen during the course of the study.

Location data were downloaded from the device and were converted for use in ArcGIS Version 9.3 (ESRI 2011). Location points from the first $30 \mathrm{~min}$ were removed, as during this period the owner would have been fitting and re-adjusting the harness.

Data analysis

\section{Ranging area}

Ranging areas were estimated using both $95 \%$ and $100 \%$ minimum convex polygons (MCPs) using Home Range Extension software (Rodgers et al. 2007). MCPs were used, first, to allow comparisons with previous studies and, second, because of the temporally correlated nature of these data. $95 \%$ MCPs were used as a measure of the area typically covered during each $24 \mathrm{~h}$ period (hereafter 'daily area ranged' or DAR) and $100 \%$ MCPs were used as a measure of the maximum daily area ranged (MDAR). Each location was classified as day or night, calculated using the daily sunrise and sunset times. MCPs were calculated for each day sampled and the mean was used to get an average $95 \%$ and $100 \%$ MCP for each cat within each season.

Land use data were derived from the Ordnance Survey Mastermap collection (EDINA, University of Edinburgh). Each daily 95 and $100 \% \mathrm{MCP}$ was cut from the Mastermap layer, and the resulting areas for each habitat category were extracted for each range. Twenty one habitat categories occurred within the study site, and these were combined to form three broad categories: urban land use (buildings, roads etc.), green land use (grassland, woodland, etc.) and private gardens (Appendix 1).

To normalise data for analysis, mean MCP areas were square root transformed. All data analyses were undertaken using Genstat (12th edition). Day and night effects and seasonal effects on range area were analysed using paired sample $t$-tests, and sex effects were analysed with unpaired $t$-tests.

\section{Habitat effects}

The relationship between habitat availability (measured as habitat available within a $350 \mathrm{~m}$ radius of the cat's home; distance based on figures from Lilith et al. (2008) and results of this study) and the habitat composition of the cat's DAR was analysed in two ways. First, Jacob's D Index (Jacobs 1974) was used. Jacob's Index is calculated as D $=(r-p) /(r+p-2 r p)$, where $\mathrm{D}$ provides an indication of how habitat availability influences preference, $\mathrm{r}$ is the proportion of habitat utilised and $\mathrm{p}$ is the proportion of habitat available. $\mathrm{D}$ ranges from +1 (complete preference), through 0 (no influence) to -1 (complete avoidance). The $95 \%$ confidence intervals are calculated for $\mathrm{D}$; if 0 is not included in the range, then a significant $(P<0.05)$ habitat preference or avoidance is supported.

Second, compositional analysis was performed following Aebischer et al. (1993) and Dickson and Beier (2002). Here, additive log ratios were calculated for garden and green habitats, the proportion of urban habitat as the denominator. These ratios were calculated for both habitat available and habitat used; if there is no habitat preference then the difference of the ratios will not be significantly different from zero. An overall comparison is made by calculating Wilks' lambda $(\Lambda)$, then transforming this into the test statistic $(=\mathrm{N} \times \ln (\Lambda))$ where $\mathrm{N}$ is the number of cats studied. Degrees of freedom are calculated as the number of habitat types available -1 . The test statistic approximates the $\chi^{2}$ distribution. If a significant $(p<0.05)$ 
overall effect is found, then relative habitat use can be compared using a series of paired t-tests (Dickson and Beier 2002).

To test whether range size was influenced by habitat availability (within $350 \mathrm{~m}$ radius of home) or habitats used (in DAR), Pearson correlation analyses were performed between ranging characteristics (day and night DAR and MDAR respectively) and the difference of the $\log$ ratios of habitats used.

\section{Results}

Twenty cats were tracked in the summer session, with $14(11 \hat{\jmath}, 3 q)$ continuing through to the winter. The loss of cats was due to cat deaths, householders moving home, or householders withdrawing from the study. The average age of the study cats was 7.4 years (range 1-16 years). Of the eight $24 \mathrm{~h}$ tracking periods each season, the mean number completed by each cat was 7.0 (range: $3-8$ ) and 6.7 (range: $3-8$ ) in summer and winter, respectively; on average, those cats tracked in both seasons completed 11.7 (range: 11-16) tracking periods (Table 2).

Table 2 Mean daily (95\% minimum convex polygon [MCP]) and maximum daily (100\% MCP) area (ha) ranged by each cat tracked during the course of the study. Columns headed maximum denote largest range area recorded for each individual

\begin{tabular}{|c|c|c|c|c|c|}
\hline \multirow[t]{2}{*}{ Cat } & \multirow{2}{*}{$\begin{array}{l}\text { No. of days } \\
\text { tracked }\end{array}$} & \multicolumn{2}{|c|}{ Daily area ranged $(95 \% \mathrm{MCP})(\mathrm{ha})$} & \multicolumn{2}{|c|}{ Maximum daily area ranged $(100 \% \mathrm{MCP})$ (ha) } \\
\hline & & Mean $[95 \% \mathrm{CI}]$ & Maximum & Mean $[95 \% \mathbf{C I}]$ & Maximum \\
\hline 1 & 6 & $4.23[2.76-5.71]$ & 6.24 & $8.22[4.82-11.62]$ & 16.28 \\
\hline 2 & 15 & $1.95[1.41-2.49]$ & 4.71 & $8.83[6.18-11.48]$ & 17.54 \\
\hline 3 & 15 & $1.10[0.82-1.37]$ & 2.07 & $4.14[2.36-5.92]$ & 11.69 \\
\hline 4 & 13 & $1.27[0.87-1.66]$ & 2.44 & $3.37[2.15-4.59]$ & 7.80 \\
\hline 5 & 11 & $2.13[0.79-3.32]$ & 3.32 & $9.10[3.63-14.57]$ & 33.78 \\
\hline 6 & 10 & $2.26[1.96-2.56]$ & 3.32 & $7.61[4.69-10.52]$ & 16.67 \\
\hline 7 & 14 & $2.66[1.73-3.58]$ & 7.55 & $8.34[5.43-11.26]$ & 23.03 \\
\hline 8 & 5 & $0.99[0.73-1.25]$ & 1.34 & $2.74[1.16-4.31]$ & 5.65 \\
\hline 9 & 8 & $1.51[1.28-1.74]$ & 2.07 & 8.78 [6.34-11.21] & 15.55 \\
\hline 10 & 8 & $1.0[0.74-1.26]$ & 1.52 & $1.69[1.21-2.16]$ & 2.61 \\
\hline 11 & 14 & $2.22[1.60-2.84]$ & 5.49 & 8.33 [5.68-10.97] & 21.67 \\
\hline 12 & 16 & $1.87[1.53-2.21]$ & 3.24 & 10.59 [7.75-13.43] & 26.89 \\
\hline 13 & 5 & 1.68 [1.19-2.17] & 2.61 & 5.45 [2.95-7.96] & 8.43 \\
\hline 14 & 16 & $2.77[2.39-3.16]$ & 4.62 & $10.58[8.32-12.83]$ & 22.70 \\
\hline 15 & 12 & $1.23[0.97-1.50]$ & 1.99 & $3.20[2.32-4.08]$ & 5.89 \\
\hline 16 & 3 & $1.23[1.03-1.43]$ & 1.43 & $3.53[3.38-3.68]$ & 3.67 \\
\hline 17 & 5 & $3.68[2.75-4.60]$ & 5.42 & 11.15 [8.93-13.37] & 13.80 \\
\hline 18 & 12 & $1.70[1.23-2.16]$ & 3.36 & 4.16 [2.29-6.04] & 10.11 \\
\hline 19 & 16 & $1.87[1.69-2.06]$ & 2.55 & $5.37[4.13-6.61]$ & 11.02 \\
\hline 20 & 12 & $1.92[1.64-2.19]$ & 2.98 & $7.07[5.74-8.40]$ & 10.77 \\
\hline Mean & 10.8 & $1.94[1.80-2.09]$ & 3.41 & $6.88[6.21-7.55]$ & 14.28 \\
\hline
\end{tabular}


Ranging area and maximum ranging area

No significant differences were found in the daily area ranged (paired $t$-test: $95 \% \mathrm{MCP}$; $\left.\mathrm{t}_{13}=-1.64, p=0.124\right)$ or the maximum daily area ranged $\left(100 \% \mathrm{MCP} ; \mathrm{t}_{13}=1.23, p=0.241\right)$ between seasons. As no seasonal differences were evident, the data have been combined in subsequent analyses.

No significant differences were found between males and females with respect to daily (independent sample $t$-test: $\left.\mathrm{t}_{19}=1.36, p=0.190\right)$ or maximum daily $\left(\mathrm{t}_{19}=1.31, p=0.207\right)$ area ranged. Mean DAR was 1.94 ha (95 \% CI: 1.80-2.09 ha); mean MDAR was 6.88 ha (95 \% CI: 6.21-7.55 ha) (Table 2). Maximum values for DAR and MDAR were 7.55 ha (mean: 3.41 ha) and 33.78 ha (mean: 14.28 ha) respectively (Table 2 ).

There was a significant difference in the mean daily area ranged during the day (1.84 ha) and night $(2.74 \mathrm{ha})$ (paired $t$-test: $\left.\mathrm{t}_{19}=-4.66, p<0.001\right)$. The result for maximum daily area ranged approached significance $\left(\mathrm{t}_{19}=-2.03, p=0.057\right)$.

\section{Habitat effects}

Analysis of habitat selection showed that cats had more garden and green habitats in their ranging area that expected; urban habitats were avoided ( $p<0.05$ for each; Fig. 1). Formal compositional analysis supported this result $\left(\chi^{2}=28.16\right.$, d.f. $\left.=2, p<0.001\right)$. Detailed inspection showed that there was a significant preference for garden (paired $t$-test: $t_{19}=5.23$, $p<0.001$ ) and green habitats over urban (paired $t$-test: $\mathrm{t}_{19}=2.78, p=0.012$ ), but no significant difference between relative amount of green and garden habitats in ranging areas, when availability was considered (paired $t$-test: $\mathrm{t}_{19}=0.48, p=0.64$ ).

As range areas differed significantly between day and night, their relationships with habitat availability and use were investigated separately. As there was no significant difference in relative garden and green space use, these were considered together and the log-ratio of both to urban habitat was used as the explanatory variable. There was no significant effect of habitat used or habitat available on DAR or MDAR (all $p>0.2$ ).

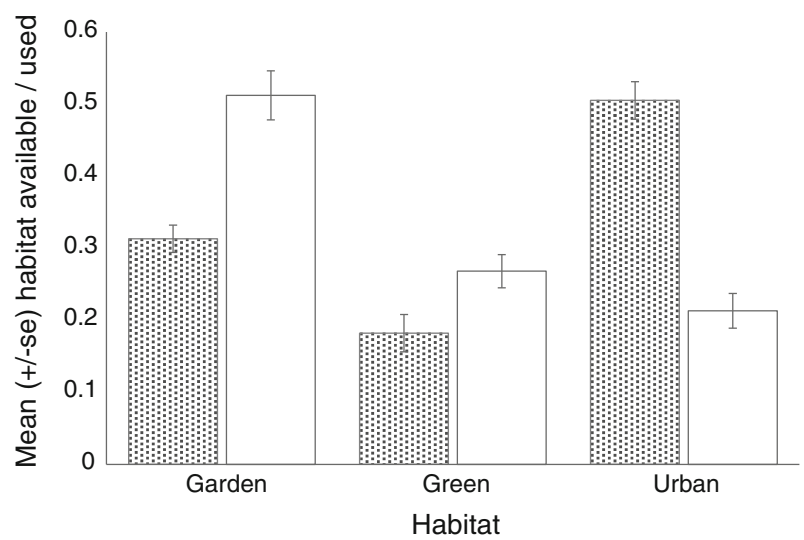

Fig. 1 Mean (+/-SE) proportion of habitat available within $350 \mathrm{~m}$ radius of owner's house (stippled bars) and proportion of habitat in ranging area (open bars) of study cats 


\section{Discussion}

In this study, ranging areas were broadly comparable to those from other countries (Table 1). Similarly, we did not detect any seasonal differences (Morgan et al. 2009), even though cats might be expected to range further in summer due to more favourable weather conditions, nor between the sexes (Barratt 1997a; Meek 2003; Morgan et al. 2009; Metsers et al. 2010; van Heezik et al. 2010). While it should be noted that the sample size was small, with a low number of female cats, they lie within the typical range of sample sizes for such studies (Barratt 1997a; Meek 2003; Kays and DeWan 2004). Furthermore, the cats utilized in this study were all neutered. In the UK this is the norm, with over $91 \%$ of adult domestic cats sterilised (Murray et al. 2009; Thomas et al. 2012).

Significant differences in ranging areas between day and night were found and near significant differences were also found in day and night maximum ranging area. Cats ranged further during the night (see also Barratt 1997a; Metsers et al. 2010) but other studies have found no difference (van Heezik et al. 2010). Although domestic cats show a greater tendency towards diurnal activity than feral cats, possibly due to their domestication (Turner and Bateson 2000), feral cats are more active at night (Alterio and Moller 1997). This study shows that pet cats still may exhibit this tendency, by ranging further. This may be in part due to decreased road traffic and less conspecific conflict, as evidence has shown the spatial movement patterns of cats are determined by busy roads and density, spatial distribution and social dominance of individual cats (Barratt 1997a).

There were no significant relationships between the daily area ranged, maximum daily area ranged and habitat type. This is unexpected, as an a priori expectation may be that cats would roam over a wider area if less suitable habitat was available. However, cats did vary in habitat preferences, spending disproportionately more time in gardens and other green habitats, than urban habitats. Taken together, these results suggest that while habitat availability does not affect the ranging area, it does influence habitat use, with cats spending more time in gardens and green areas. This in itself is unsurprising, given that ranging cats will be seeking prey and avoiding disturbance.

It is vital when considering the effects of cat predation on wild bird and small mammal populations to understand how cats use their environment. When discussing the mitigation techniques that could be implemented, the banning of cat ownership near ecologically sensitive areas, such as heathland, has been proposed (Leake and Cracknell 2006). The acceptability of this measure to residents within the UK is mixed though, with less than half of respondents questioned feeling that this is a justifiable approach (Thomas et al. 2012). This may become more acceptable to the public once it is determined whether or not cats are detrimentally affecting wildlife populations.

Lilith et al. (2008) has suggested a buffer zone concept, whereby developments, or households owning cats, may be banned within a certain distance from an area of important wildlife value. Data from the radio-tracking of rural and urban cats in Australia produced a figure of $360 \mathrm{~m}$ that would be acceptable as a buffer zone (Lilith et al. 2008). Within our study, the largest maximum daily area ranged by a cat was 33.78 ha, this being equivalent to a circular area of diameter of $656 \mathrm{~m}$. However, owners' homes are not generally located at the extreme periphery of their pet's ranges, such that the radius $(328 \mathrm{~m})$ may be a more useful metric for estimating the appropriate size for a buffer zone. Furthermore, it could be argued that is an overly conservative approach. For 
example, estimates based on the mean MDAR (6.88 ha) and mean DAR (1.94 ha) would be substantially smaller, radii of $148 \mathrm{~m}$ and $79 \mathrm{~m}$ respectively, and caution should also be taken due to the small sample size in this study.

One additional factor that may also affect the ranging behaviour of cats that has not been considered in this study is the density of other cats and whether domestic cats are quasiterritorial (feral cats typically are semi-social and territorial: Genovesi et al. 1995; Hall et al. 2000). If it were the case that range size was negatively affected by cat density, then higher densities of cats may decrease range sizes and indeed this may explain the differences in nocturnal maximum ranging size considered above. It would be important to understand these effects, as it could be the case that by reducing numbers of cats in urban areas it may increase the areas ranged by those that remain; such density-dependent responses would suggest that buffer zones would need to be larger than those identified from studies of existing cat populations. Again this would suggest that managers should err on the side of caution.

Domestic cats are the most common mammalian predator in the UK, and as a result of their close links with people, cat densities can be exceptionally high in urban areas. With the recent growth in interest in urban ecology, it has become clear that many populations of birds and mammals are on the edge of sustainability in these human-modified habitats (e.g. Blair 2004; Goddard et al. 2009), as urban animals respond to the challenges of living in highly altered and fragmented habitats. While native predators are still present in these habitats (albeit in lower densities, e.g. sparrowhawk Accipiter nisus; Chamberlain et al. 2009), human behaviour results in exceptionally high populations of an introduced predator, the domestic cat. This study, the first of its kind in the UK, demonstrates that to be effective in safeguarding important wildlife habitats, any zone of restricted cat ownership would need to be in the order of 300-400 m.

Acknowledgments We wish to thank the cat owners and cats who took part in this research. RLT was supported by a NERC doctoral training award. Requests for original data may be made to the corresponding author.

Open Access This article is distributed under the terms of the Creative Commons Attribution License which permits any use, distribution, and reproduction in any medium, provided the original author(s) and the source are credited.

\section{Appendix 1}

Original land-use categories and details of their re-classification.

\begin{tabular}{lll}
\hline Urban land use & Green land use & Private Gardens \\
Manmade surface or step & Natural surface & Gardens \\
Path & Coniferous trees & \\
Road & Coniferous-scattered & \\
Road traffic calming & Nonconiferous trees \\
Structure & Nonconiferous-scattered \\
Track & Orchard \\
Unclassified & Rough grassland \\
Unknown surface & Scrub \\
Archway & Inland water \\
Building & \\
Greenhouses & \\
\hline
\end{tabular}




\section{References}

Aebischer NJ, Robertson PA, Kenward RE (1993) Compositional analysis of habitat use from animal radiotracking data. Ecology 74(5):1313-1325

Alterio N, Moller H (1997) Daily activity of stoats (Mustela erminea), feral ferrets (Mustela furo) and feral house cats (Felis catus) in coastal grassland, Otago Peninsula, New Zealand. New Zeal J Ecol 21(1):89-95

Apps PJ (1986) Home ranges of feral cats on Dassen Island. J Mammal 67(1):199-200

Attuquayefio DK, Gorman ML, Wolton RJ (1986) Home range sizes in the wood mouse Apodemus sylvaticus: habitat, sex and seasonal differences. J Zool 210(1):45-53

Baker PJ, Bentley AJ, Ansell RJ, Harris S (2005) Impact of predation by domestic cats Felis catus in an urban area. Mammal Rev 35(3-4):302-312

Baker PJ, Molony SE, Stone E, Cuthill IC, Harris S (2008) Cats about town: is predation by free-ranging pet cats Felis catus likely to affect urban bird populations? Ibis 150:86-99

Barratt DG (1997a) Home range size, habitat utilisation and movement patterns of suburban and farm cats Felis catus. Ecography 20(3):271-280

Barratt DG (1997b) Predation by house cats, Felis catus (L), in Canberra, Australia.1. Prey composition and preference. Wild Res 24(3):263-277

Barratt DG (1998) Predation by house cats, Felis catus (L.), in Canberra, Australia. II. Factors affecting the amount of prey caught and estimates of the impact on wildlife. Wild Res 25(5):475-487

Beckerman AP, Boots M, Gaston KJ (2007) Urban bird declines and the fear of cats. Anim Cons 10(3):320-325

Biro Z, Szemethy L, Heltai M (2004) Home range sizes of wildcats (Felis silvestris) and feral domestic cats (Felis silvestris $f$. catus) in a hilly region of Hungary. Mammalian Biology-Zeitschrift fur Saugetierkunde 69(5): 302-310

Blair R (2004) The effects of urban sprawl on birds at multiple levels of biological organization. Ecol Soc 9(5):2

Bonnington C, Gaston KJ, Evans KL (2013) Fearing the feline: domestic cats reduce avian fecundity through trait-mediated indiect effects that increase nest predation by other species. J Appl Ecol 50(1):15-24

Burt WH (1943) Territoriality and home range concepts as applied to mammals. J Mamm 24(3):346-352

Chamberlain DE, Glue DE, Toms MP (2009) Sparrowhawk Accipiter nisus presence and winter bird abundance. J Ornithol 150:247-254

Churcher PB, Lawton JH (1987) Predation by domestic cats in an English-village. J Zool 212:439-455

Crooks KR, Soulé ME (1999) Mesopredator release and avifaunal extinctions in a fragmented system. Nature 400(6744):563-566

Dickson BG, Beier P (2002) Home-range and habitat selection by adult cougars in southern California. J Wild Manag 66(4):1235-1245

Edwards GP, De Preu N, Shakeshaft BJ, Crealy IV, Paltridge RM (2001) Home range and movements of male feral cats (Felis catus) in a semiarid woodland environment in central Australia. Aust Ecol 26(1):93-101

Fitzgerald BM, Turner DC (2000) Hunting behaviour of domestic cats and their impact on prey populations. In: Turner DC, Bateson P (eds) The domestic cat, 2nd edn. Cambridge University Press, Cambridge

Genovesi P, Besa M, Toso S (1995) Ecology of a feral cat Felis catus population in an agricultural area of northern Italy. Wildlife Biol 1(4):233-237

Goddard MA, Dougill AJ, Benton TG (2009) Scaling up from gardens: biodiversity conservation in urban gardens. Trend Ecol Evol 25(2):90-98

Hall LS, Kasparian MA, Van Vuren D, Kelt DA (2000) Spatial organization and habitat use of feral cats (Felis catus L.) in Mediterranean California. Mammalia 64(1):19-28

Harper GA (2007) Habitat selection of feral cats (Felis catus) on a temperate, forested island. Aust Ecol 32(3): 305-314

Harris S, Morris P, Wray S, Yalden D (1995) A review of British mammals: population estimates and conservation status of British mammals other than cetaceans.

Horn JA, Mateus-Pinilla N, Warner RE, Heske EJ (2011) Home range, habitat use, and activity patterns of freeroaming domestic cats. J Wildlife Manag 75(5):1177-1185

Huck M, Davison J, Roper TJ (2008) Comparison of two sampling protocols and four home-range estimators using radio-tracking data from urban badgers Meles meles. Wildlife Biol 14(4):467-477

Jacobs J (1974) Quantitative measurement of food selection. A modification of the forage ratio and Ivlev's electivity index. Oecologia 14:413-417

Kays RW, DeWan AA (2004) Ecological impact of inside/outside house cats around a suburban nature preserve. Anim Conserv 7:273-283

Konecny MJ (1987) Home range and activity patterns of feral house cats in the Galapagos-Islands. Oikos 50(1): $17-23$

Leake J, Cracknell D (2006) Cat ban may allow housing on green belt. The Times

Liberg O (1980) Spacing patterns in a population of rural free roaming domestic cats. Oikos 35(3):336-349 
Liberg O, Sandell M, Pontier D, Natoli E (2000) Density, spatial organisation and reproductive tactics in the domestic cat and other felids. In: Turner DC, Bateson P (eds) The domestic cat: the biology of its behaviour, 2nd edn. Cambridge University Press, Cambridge, pp 119-147

Lilith M, Calver M, Garkaklis M (2008) Roaming habits of pet cats on the suburban fringe in Perth, Western Australia: what size buffer zone is needed to protect wildlife in reserves? Too Close for Comfort : Contentious Issues in Human-Wildlife Encounters. Royal Zoological Soc New South. Wales, Mosman NSW

Lilith M, Calver M, Garkaklis M (2010) Do cat restrictions lead to increased species diversity or abundance of small and medium-sized mammals in remnant urban bushland? Pac Conserv Biol 16(3):162-172

Loss SR, Will T, Marra PP (2013) The impact of free-ranging domestic cats on wildlife of the United States. Nat Commun 4:1396

Loyd KAT, Hernandez SM, Carroll JP, Abernathy KJ, Marshall GJ (2013) Quantifying free-roaming domestic cat predation using animal-borne video cameras. Biol Conserv 160:183-189

Maclean M (2007) Impact of domestic cat predation on bird and small mammal populations. $\mathrm{PhD}$ thesis, University of Exeter, UK

Meek PD (2003) Home range of house cats Felis catus living within a national park. Austral Mammal 25(1):5160

Metsers EM, Seddon PJ, van Heezik YM (2010) Cat-exclusion zones in rural and urban-fringe landscapes: how large would they have to be? Wildlife Res 37(1):47-56

Mirmovitch V (1995) Spatial-organization of urban feral cats (Felis catus) in Jerusalem. Wildlife Res 22(3):299310

Morgan SA, Hansen CM, Ross JG, Hickling GJ, Ogilvie SC, Paterson AM (2009) Urban cat (Felis catus) movement and predation activity associated with a wetland reserve in New Zealand. Wildlife Res 36(7): $574-580$

Murray JK, Roberts MA, Whitmarsh A, Gruffydd-Jones TJ (2009) Survey of the characteristics of cats owned by households in the UK and factors affecting their neutered status. Vet Rec 164(5):137-141

Murray JK, Browne WJ, Roberts MA, Whitmarsh A, Gruffydd-Jones TJ (2010) Number and ownership profiles of cats and dogs in the UK. Vet Rec 166(6):163-168

Naidenko SV, Hupe K (2002) Seasonal changes in home range use in feral tomcats in solling, central Germany. Zoologichesky Zhurnal 81(11):1371-1381

Page RJC, Ross J, Bennett DH (1992) A study of the home ranges, movements and behavior of the feral cat population at Avonmouth Docks. Wildlife Res 19(3):263-277

Recio MR, Mathieu R, Maloney R, Seddon PJ (2010) First results of feral cats (Felis catus) monitored with GPS collars in New Zealand. New Zeal J Ecol 34(3):288-296

Robertson ID (1998) Survey of predation by domestic cats. Austral Vet J 76(8):551-554

Rodgers AR, Carr AP, Beyer HL, Smith L, Kie JG (2007) HRT: Home range tools for ArcGIS. Version 1.1. Ontario Ministry of Natural Resources, Centre for Northern Forest Ecosystems Research, Ontario, Canada

Schmidt PM, Lopez RR, Collier BA (2007) Survival, fecundity, and movements of free-roaming cats. J Wildlife Manag 71(3):915-919

Schmutz JA, White GC (1990) Error in telemetry studies: effects of animal movement on triangulation. J Wildlife Manag 54(3):506-510

Sims V, Evans KL, Newson SE, Tratalos JA, Gaston KJ (2008) Avian assemblage structure and domestic cat densities in urban environments. Divers Distrib 14(2):387-399

Thomas RL, Fellowes MDE, Baker PJ (2012) Spatio-temporal variation in predation by urban domestic cats (Felis catus) and the acceptability of possible management actions in the UK. PLoS One 7(11):e49369

Turner DC, Bateson P (2000) The domestic cat: The biology of its behaviour, 2nd edn. Cambridge University Press, Cambridge

van Heezik Y, Smyth A, Adams A, Gordon J (2010) Do domestic cats impose an unsustainable harvest on urban bird populations? Biol Conserv 143(1):121-130

Woods M, McDonald RA, Harris S (2003) Predation of wildlife by domestic cats Felis catus in Great Britain. Mammal Rev 33(2):174-188 